Objectives: To test the hypothesis that low or absent ERAP1 activity alters CD8 T cell immunogenicity through changes in the HLA-B51 peptidome and shapes the CD8 T cell immune response in affected subjects.

Methods: We generated HLA-B51 ${ }^{+}$ERAP1 KO LCL clones using CRISPR-Cas9, performed mass spectrometry of the immunoprecipitated MHC-class I peptidome with subsequent computational deconvolution for HLA-B51-binding peptides. We then assessed single cell (ICS), bulk (ELISA) and proliferative (CFSE) CD8 effector (IFNg, granzyme B, perforin) $\mathrm{T}$ cell responses through stimulation of allogeneic donor cells with WT vs KO LCL and determined ERAP1 haplotypes in 49 untreated Turkish BD subjects with ocular and/ or major vascular involvement as well as healthy donors (HD) whose PBMC were profiled using 6 multicolour flow cytometry panels. Results: WT and KO peptidomes differed significantly ( $p<0.0005$ Fisher's exact test) with a distinctive shift of peptide length frequencies exceeding 9-mer (binding optimum) in the KO vs WT. This held true for computationally deconvoluted HLA-B51 binders. IFNg secretion from CD8 T cells stimulated with $\mathrm{KO} L C L$ was significantly different from WT (ICS, $p=0.0006$; ELISA, $p=0.0059$ ) as were CD8 T cell proliferation and ICS of perforin/granzyme $\mathrm{B}^{+} \mathrm{CD} 8 \mathrm{~T}$ cells. Analysis of $133 \mathrm{~T}, \mathrm{~B}, \mathrm{NK}$ and monocyte cell populations revealed predominance of CD8 T and NKT cell subset in HLA-B51+/Hap10+ BD vs HLA-B51+/Hap10- BD and HD, accounting for $80 \%$ of all populations reaching significance $(p<0.05$, Mann-Whitney). Naive and effector memory CD8 T cell subsets were inversely correlated. Cohen's effect sizes were large $(>0.8)$ or very large $(>1.2)$. Conclusion: We show that absence of functional ERAP1 alters human CD8 T cell immunogenicity. This is mediated by an HLA-class I peptidome with propensity for longer peptides above 9mer and suggests loss or de-novo presentation of peptide-HLA-B51 complexes to cognate CD8 TCR. The reciprocal changes in antigen- experienced vs naive CD8 T cell subsets in affected subjects point to biologic significance of HLA-B51/Hap10 in BD. Collectively, our findings suggest that an altered HLA-B51 peptidome modulates immunogenicity of CD8 effector T cells in ERAP1-Hap10 carriers with BD and identify targets for future drug development. References:

[1] Kirino, Y., G. Bertsias, Y. Ishigatsubo, N. Mizuki, I. Tugal-Tutkun, E. Seyahi, Y. Ozyazgan, F. S. Sacli, B. Erer, H. Inoko, Z. Emrence, A. Cakar, N. Abaci, D. Ustek, C. Satorius, A. Ueda, M. Takeno, Y. Kim, G. M. Wood, M. J. Ombrello, A. Meguro, A. Gul, E. F. Remmers, and D. L. Kastner. 2013. 'Genome-wide association analysis identifies new susceptibility loci for Behcet's disease and epistasis between HLA-B*51 and ERAP1', Nat Genet, 45: 202-7.

[2] Takeuchi, M., M. J. Ombrello, Y. Kirino, B. Erer, I. Tugal-Tutkun, E. Seyahi, Y. Ozyazgan, N. R. Watts, A. Gul, D. L. Kastner, and E. F. Remmers. 2016. 'A single endoplasmic reticulum aminopeptidase-1 protein allotype is a strong risk factor for Behcet's disease in HLA-B*51 carriers', Ann Rheum Dis, 75: 2208-11. Disclosure of Interests: Arshed F. Al-Obeidi: None declared, Ann Cavers: None declared, Yesim Ozguler: None declared, Olivier Manches: None declared, Hua Zhong: None declared, Berna Yurttas: None declared, Beatrix Ueberheide: None declared, Gulen Hatemi Grant/research support from: BMS, Celgene Corporation, Silk Road Therapeutics - grant/research support, Consultant of: Bayer, Eli Lilly - consultant, Speakers bureau: AbbVie, Mustafa Nevzat, Novartis, UCB speaker, Matthias Kugler: None declared, Johannes Nowatzky: None declared DOI: 10.1136/annrheumdis-2020-eular.3885

\section{OP0033 CELL ARTERITIS. A MULTICENTER REAL-LIFE STUDY OF 134 PATIENTS}

M. Calderón-Goercke ${ }^{1}$, D. Prieto-Peña ${ }^{1}$, S. Castañeda ${ }^{2}$, C. Moriano ${ }^{2}$, E. BecerraFernández $^{2}$, M. Revenga ${ }^{2}$, N. Alvarez-Rivas ${ }^{2}$, C. Galisteo ${ }^{2}$, Á. Prior-Español ${ }^{2}$, E. Galindez ${ }^{2}$, C. Hidalgo ${ }^{2}$, S. Manrique Arija ${ }^{2}$, E. De Miguel ${ }^{2}$, E. Salgado-Pérez², V. Aldasoro², I. Villa-Blanco ${ }^{2}$, S. Romero-Yuste ${ }^{2}$, J. Narváez ${ }^{2}$, C. GomezArango $^{2}$, E. Perez-Pampín ${ }^{2}$, R. Melero ${ }^{2}$, F. Sivera ${ }^{2}$, A. Olive ${ }^{2}$, M. Álvarez del Buergo $^{2}$, L. Marena Rojas², C. Fernández-López ${ }^{2}$, F. Navarro², E. Raya², B. Arca ${ }^{2}$, R. Solans-Laqué ${ }^{2}$, A. Conesa ${ }^{2}$, C. Vázquez ${ }^{2}$, J. A. Román-Ivorra ${ }^{2}$, P. Lluch ${ }^{2}$, P. Vela-Casasempere ${ }^{2}$, C. Torres-Martín ${ }^{2}$, J. C. Nieto², C. OrdasCalvo $^{2}$, C. Luna-Gomez ${ }^{2}$, F. J. Toyos Sáenz de Miera², N. Fernández-Llanio², A. García ${ }^{2}$, J. L. Hernández ${ }^{1}$, M. A. González-Gay ${ }^{1}$, R. Blanco ${ }^{1} .{ }^{1}$ HUM. Valdecilla, Santander, Spain; ${ }^{2}$ Reference Centers from Spain, Spain, Spain

Background: Tocilizumab (TCZ) is the only biological agent approved in Giant Cell Arteritis (GCA). There is general agreement on the initial and the standard maintenance dose of TCZ. However, information on duration and optimization of TCZ in GCA is scarce. Objectives: Our aim was to assess efficacy and safety of TCZ therapy optimization in an unselected wide series of GCA in clinical practice.

Methods: Multicenter study, 134 patients with GCA who received TCZ due to inefficacy/adverse events of previous therapy. Once complete remission was reached and based on a shared decision between patient and physician TCZ was optimized in some cases. Optimization was done by decreasing the dose and/or prolonging the TCZ dosing interval progressively.

Results: 134 GCA patients treated with TCZ $(101 w / 33 \mathrm{~m})$; mean age $73.0 \pm 8.8$ years. TCZ was administered IV to 106 (79.1\%) patients and SC to 28 (20.9\%). TCZ was optimized in $43(32.1 \%)$ patients. No demographic, clinical manifestations or laboratory data differences had been found at TCZ onset (TABLE). After a follow up of 12 [6-15.5] months, and a complete remission for 6 [3-12] months; the first TCZ optimization was performed. Median prednisone dose at first TCZ optimization was 2.5 [0-5] mg/day. TCZ IV was optimized from 8 to $4 \mathrm{mg} / \mathrm{kg} / 4$ weeks in 12 of 106 (11.3\%) and from $162 \mathrm{mg} / \mathrm{SC} /$ week to $162 \mathrm{mg} / \mathrm{SC} / 2$ weeks in 9 of $28(32.1 \%)$ cases. Five (11.6\%) of the 43 optimized cases relapsed. In 4 cases, the relapses were treated increasing TCZ up to the pre-optimization dose, in 1 case the route of administration was change ( $4 \mathrm{mg} / \mathrm{kg} / 4$ week to $162 \mathrm{mg} / \mathrm{SC} /$ week). In 8 of 43 optimized patients (18.6\%), it was possible to withdraw TCZ after complete remission for 30 [16.25-45.75] months. Regarding adverse events and severe infections were similar in both groups. The mean TCZ treatment costs were lower in the optimized group.

Conclusion: Once remission is reached in GCA patients under TCZ treatment, optimization of TCZ may be performed. Based on our experience it could be performed by reducing the dose with IV TCZ or by prolonging dosing interval with SC TCZ. References:

[1] Calderón-Goercke M et al. Semin Arthritis Rheum 2019 Aug;49(1): 126-135

TABLE

\begin{tabular}{|c|c|c|c|}
\hline & $\begin{array}{l}\text { OPTIMIZED-TCZ } \\
\text { GROUP }(n=43)\end{array}$ & $\begin{array}{l}\text { NON-OPTIMIZEDTCZ } \\
\text { GROUP }(n=91)\end{array}$ & $\mathbf{p}$ \\
\hline \multicolumn{4}{|l|}{$\begin{array}{l}\text { BASAL FEATURES AT TCZ ONSET } \\
\text { GENERAL FEATURES }\end{array}$} \\
\hline Age, years, mean \pm SD & $68.9 \pm 8.7$ & $71.4 \pm 8.5$ & 0.125 \\
\hline Sex, female/male $\mathrm{n}(\%)$ & $32 / 10$ & $68 / 24$ & 0.779 \\
\hline $\begin{array}{l}\text { Time from GCA diagnosis to TCZ onset } \\
\text { (months), median [IQR] }\end{array}$ & $19.5[7.75-45]$ & $10.5[4-25]$ & 0.047 \\
\hline \multicolumn{4}{|l|}{ SYSTEMIC MANIFESTATIONS } \\
\hline Fever, $\mathrm{n}(\%)$ & $1(2.4)$ & $8(8.7)$ & 0.176 \\
\hline Constitutional syndrome, $\mathrm{n}(\%)$ & $11(26.2)$ & $19(20.7)$ & 0.476 \\
\hline \multicolumn{3}{|l|}{ ISCHEMIĆ MANIFESTATIONS } & 0.052 \\
\hline Visual involvement, $\mathrm{n}(\%)$ & $5(11.9)$ & $23(25)$ & 0.084 \\
\hline Headache, $n(\%)$ & $26(61.9)$ & $42(45.7)$ & 0.081 \\
\hline Jaw claudication, n(\%) & $1(2.4)$ & $11(12)$ & 0.072 \\
\hline \multicolumn{4}{|l|}{ CORTICOSTEROIDS AT TCZ ONSET } \\
\hline Prednisone dose, $\mathrm{mg} / \mathrm{d}$ mean (SD) & $\begin{array}{l}15.1 \pm 11.1 \\
24[18-27]\end{array}$ & $\begin{array}{l}25 \pm 17.4 \\
6[3-18]\end{array}$ & 0.001 \\
\hline \multicolumn{4}{|l|}{ (MONTHS), MEDIAN [IQR] } \\
\hline Relapses, $\mathrm{n}(\%)$ & $5(11.6)$ & $5(5.5)$ & 0.207 \\
\hline End follow-up remission, $\mathrm{n}(\%)$ & $40(93)$ & $84(92)$ & 0.99 \\
\hline Severe side efects, $n(\%)$ & $14(32.6)$ & $22(24.2)$ & 0.307 \\
\hline Seriuos infections, $\mathrm{n}(\%)$ & $6(14)$ & $10(11)$ & 0.878 \\
\hline \multicolumn{4}{|l|}{ Cost, (mean) euros per year } \\
\hline IV & 7538.4 & 11726.4 & - \\
\hline $\mathrm{SC}$ & 7329.0 & 11726.4 & - \\
\hline
\end{tabular}

Disclosure of Interests: Monica Calderón-Goercke: None declared, D. Prieto-Peña: None declared, Santos Castañeda: None declared, Clara Moriano: None declared Elena Becerra-Fernández: None declared, Marcelino Revenga: None declared, Noelia Alvarez-Rivas: None declared, Carles Galisteo: None declared, Águeda Prior-Español: None declared, E. Galindez: None declared, Cristina Hidalgo: None declared, Sara Manrique Arija: None declared, Eugenio de Miguel Grant/research support from: Yes (Abbvie, Novartis, Pfizer), Consultant of: Yes (Abbvie, Novartis, Pfizer), Paid instructor for: yes (AbbVie, Novartis, Pfizer, MSD, BMS, UCB, Roche, Grunental Janssen, Sanofi), Speakers bureau: yes (AbbVie, Novartis, Pfizer, MSD, BMS, UCB Roche, Grunental, Janssen, Sanofi), Eva Salgado-Pérez: None declared, Vicente Aldasoro Speakers bureau: Roche, Abbvie, MSD, UCB, Pfizer, Menarini, Grunenthal, Gebro, Novartis, Janssen, Ignacio Villa-Blanco Consultant of: UCB, Speakers bureau: Novartis, MSD, Lilly, Susana Romero-Yuste: None declared, J. Narváez: None declared, Catalina Gomez-Arango: None declared, Eva Perez-Pampín: None declared, Rafael Melero: None declared, Francisca Sivera: None declared, Alejandro Olive: None declared, María Álvarez del Buergo: None declared, Luisa Marena Rojas: None declared, Carlos Fernández-López: None declared, Francisco Navarro: None declared, Enrique Raya: None declared, Beatriz Arca: None declared, Roser SolansLaqué: None declared, Arantxa Conesa: None declared, Carlos Vázquez: None declared, Jose Andrés Román-Ivorra: None declared, Pau Lluch: None declared Paloma Vela-Casasempere: None declared, Carmen Torres-Martín: None declared, Juan Carlos Nieto Speakers bureau: Pfizer, Abbvie, MSD, Novartis, Janssen, Lilly, Nor dic Pharma, BMS, Gebro, FAES Farma, Roche, Sanofi, Carmen Ordas-Calvo: None declared, Cristina Luna-Gomez: None declared, Francisco J. Toyos Sáenz de Miera: None declared, Nagore Fernández-Llanio: None declared, Antonio García: None declared, J. Luis Hernández: None declared, Miguel A González-Gay Grant/research support from: Pfizer, Abbvie, MSD, Speakers bureau: Pfizer, Abbvie, MSD, Ricardo Blanco Grant/research support from: AbbVie, MSD, and Roche, Speakers bureau: AbbVie, Pfizer, Roche, Bristol-Myers, Janssen, and MSD DOI: 10.1136/annrheumdis-2020-eular.2574

\section{Lung diseases and other comorbidities in RA}

OP0034
DOES THE RISK OF VENOUS THROMBOEMBOLISM
VARY WITH DISEASE ACTIVITY IN RHEUMATOID
ARTHRITIS?

V. Molander ${ }^{1}, \mathrm{H}$. Bower ${ }^{1}$, J. Askling ${ }^{1}{ }^{1}$ Division of Clinical Epidemiology, Department of Medicine Solna, Karolinska Institutet, Stockholm, Sweden 
Background: Patients with rheumatoid arthritis (RA) are at increased risk for venous thromboembolism (VTE), including deep vein thrombosis (DVT) and pulmonary embolism (PE) (1). Several established risk factors of VTE, such as age, immobilization and comorbid conditions, occur more often patients with RA (2). In addition, inflammation may in itself also increase VTE risk by upregulating procoagolatory factors and causing endothelial damage (3). Recent reports indicate an increased risk of VTE in RA patients treated with JAK-inhibitors (4), pointing to the need to better understand how inflammation measured as clinical RA disease activity influences VTE risk.

Objectives: To investigate the relationship between clinical RA disease activity and incidence of VTE.

Methods: Patients with RA were identified from the Swedish Rheumatology Quality Register (SRQ) between July $1^{\text {st }} 2006$ and December $31^{\text {st }} 2017$. Clinical rheumatology data for these patients were obtained from the visits recorded in SRQ, and linked to national registers capturing data on VTE events and comorbid conditions. For each such rheumatologist visit, we defined a one-year period after the visit and determined whether a VTE event had occurred within this period or not. A visit followed by a VTE event was categorized as a case, all other visits were used as controls. Each patient could contribute to several visits. The DAS28 score registered at the visit was stratified into remission (0-2.5) vs. Iow (2.6-3.1), moderate (3.2-5.1) and high (>5.1) disease activity. Logistic regression with robust cluster standard errors was used to estimate the association between the DAS28 score and VTE. Results: We identified 46,311 patients with RA who contributed data from 320,094 visits. Among these, 2,257 visits ( $0.7 \%$ of all visits) in 1345 unique individuals were followed by a VTE within the one-year window. Of these, 1391 were DVT events and 866 were PE events. Figure 1 displays the absolute probabilities of a VTE in this one-year window, and odds ratios for VTE by each DAS28 category, using DAS28 remission as reference. The one-year risk of a VTE increased from $0.5 \%$ in patients in DAS28 remission, to $1.1 \%$ in patients with DAS28 high disease activity (DAS28 above 5.1). The age- and sex-adjusted odds ratio for a VTE event in highly active RA compared to RA in remission was $2.12(95 \% \mathrm{Cl} 1.80-2.47)$. A different analysis, in which each patient could only contribute to one visit, yielded similar results.

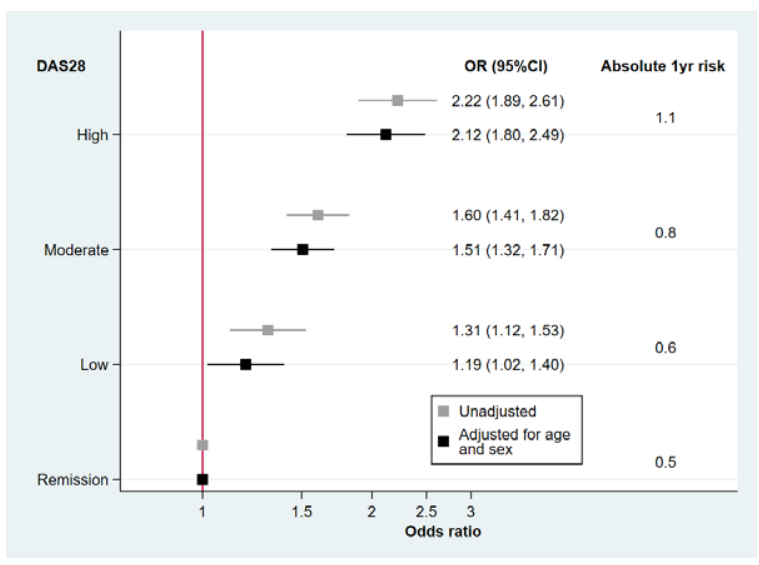

Figure 1. Odds ratios (OR) comparing the odds of VTE for DAS28 activity categories versus remission. Grey estimates are from unadjusted logistic regression models, black estimates are from logistic regression models adjusted for age and sex. Absolute one-year risk of VTE are estimated from unadjusted models.

Conclusion: This study demonstrates a strong association between clinical RA inflammatory activity as measured through DAS28 and risk of VTE. Among patients with high disease activity one in a hundred will develop a VTE within the coming year. These findings highlight the need for proper VTE risk assessment in patients with active RA, and confirm that patients with highly active RA, such as those recruited to trials for treatment with new drugs, are already at particularly elevated risk of VTE. References:

[1] Holmqvist et al. Risk of venous thromboembolism in patients with rheumatoid arthritis and association with disease duration and hospitalization. JAMA. 2012;308(13):1350-6.

[2] Cushman M. Epidemiology and risk factors for venous thrombosis. Semin Hematol. 2007;44(2):62-9.

[3] $\mathrm{Xu} \mathrm{J}$ et al. Inflammation, innate immunity and blood coagulation. Hamostaseologie. 2010;30(1):5-6, 8-9

[4] FDA. Safety trial finds risk of blood clots in the lungs and death with higher dose of tofacitinib (Xeljanz, Xeljanz XR) in rheumatoid arthritis patients; FDA to investigate. 2019.

Acknowledgments: Many thanks to all patients and rheumatologists persistently filling out the SRQ.

Disclosure of Interests: Viktor Molander: None declared, Hannah Bower: None declared, Johan Askling Grant/research support from: JA acts or has acted as PI for agreements between Karolinska Institutet and the following entities, mainly in the context of the ARTIS national safety monitoring programme of immunomodulators in rheumatology: Abbvie, BMS, Eli Lilly, Merck, MSD, Pfizer, Roche, Samsung Bioepis, Sanofi, and UCB Pharma DOI: 10.1136/annrheumdis-2020-eular.353

\section{OP0035 EXAMINATION OF INTERSTITIAL LUNG DISEASE IN PATIENTS WITH RHEUMATOID ARTHRITIS - PREVALENCE, TIME TO ONSET, AND CLINICAL CHARACTERISTICS}

J. Zhuo', Q. Zhang ${ }^{2}$, K. Knapp ${ }^{3}$, Y. Wang ${ }^{2}$, C. Gutierrez ${ }^{2}$, D. $\mathrm{He}^{2}$, L. Xie ${ }^{2}$ S. Lama ${ }^{1}$, G. Craig ${ }^{3,4} .{ }^{1}$ Bristol-Myers Squibb, Lawrenceville, NJ, United States of America; ${ }^{2}$ STATinMED Research, Ann Arbor, MI, United States of America, ${ }^{3}$ Discus Analytics, Spokane, WA, United States of America; ${ }^{4}$ Arthritis Northwest, PLLC, Spokane, WA, United States of America

Background: Interstitial lung disease (ILD) is a known extraarticular manifestation of rheumatoid arthritis (RA). Previous studies have shown variability in the prevalence of RA-ILD, as well as clinical characteristics and risk factors of RA-ILD. Objectives: To evaluate the prevalence and time to onset of ILD and compare the clinical characteristics between RA patients (pts) with or without ILD using a large US electronic medical record (EMR)-based dataset.

Methods: Pts with an initial RA diagnosis (ICD-9-CM code: 714.0; ICD-10-CM codes: M05 \& M06) during the study period (01JAN2009-20SEP2019) were included from the Discus Analytics JointMan database. The initial RA diagnosis date was defined as the index date. Pts with ILD were identified by ICD diagnosis codes or by provider indication in the JointMan record. Pts who developed ILD before RA were excluded from this analysis. The prevalence and time to onset of ILD were reported. Pt demographics, comorbidities, RA characteristics and disease activity scores were compared for 6 months prior to or on the index date (baseline period) for selected adult RA pts with available information.

Results: Among 8,963 identified RA pts, 337 (3.8\%) were diagnosed with ILD on or after RA diagnosis. The median time to ILD onset post-RA was 2.3 years, and $47 \%$ had ILD within 2 years after RA diagnosis. RA-ILD pts were significantly older than those without ILD (65.8 years vs. 59.1 years; $p<0.001$; Table 1). At baseline, a higher percentage of RA-ILD pts had history of chronic obstructive pulmonary disease, positive rheumatoid factor, rheumatoid nodules, erosive joint disease, positive anti-cyclic citrullinated peptide antibody, and joint swelling compared to RA-only pts (Table 2). The mean ESR and RA disease activity scores were also significantly higher for RA-ILD pts.

Table 1. Patient Demographics

\begin{tabular}{lccc}
\hline Patient demographics & $\begin{array}{c}\text { RA-ONLY COhort } \\
(\mathrm{N}=5,612)\end{array}$ & $\begin{array}{c}\text { RA-ild coHORT } \\
(\mathrm{N}=205)\end{array}$ & P-value \\
\hline Age, Mean \pm SD, years & $59.1 \pm 14.2$ & $65.8 \pm 11.8$ & \\
Male, N (\%) & $1,375(24.5 \%)$ & $72(35.1 \%)$ & $\mathbf{0 . 0 0 1}$ \\
Race, N (\%) & $4,014(71.5 \%)$ & $165(80.5 \%)$ & $\mathbf{0 . 0 0 5}$ \\
White & $365(6.5 \%)$ & $9(4.4 \%)$ & 0.226 \\
African American & $1,233(22.0 \%)$ & $31(15.1 \%)$ & $\mathbf{0 . 0 2 0}$ \\
Other/Missing & & & \\
\hline
\end{tabular}

Table 2. Baseline Clinical Characteristics

\begin{tabular}{|c|c|c|c|}
\hline Clinical Characteristics & $\begin{array}{l}\text { RA-ONLY COhort } \\
\qquad(\mathrm{N}=3,846)\end{array}$ & $\begin{array}{l}\text { RA-ild coHORT } \\
\qquad(\mathrm{N}=115)\end{array}$ & P-value \\
\hline $\begin{array}{l}\text { History of Chronic Obstructive Pulmonary } \\
\text { Disease, } N(\%)\end{array}$ & $102(2.7 \%)$ & $8(7.0 \%)$ & 0.006 \\
\hline Hypertension, $\mathrm{N}(\%)$ & $900(23.4 \%)$ & $23(20.0 \%)$ & 0.395 \\
\hline Serious Infection, N (\%) & $38(1.0 \%)$ & $3(2.6 \%)$ & 0.091 \\
\hline Rheumatoid Factor Positive, N (\%) & $1,388(36.1 \%)$ & $69(60.0 \%)$ & $<.001$ \\
\hline Joint Stiffness, N (\%) & $1,092(28.4 \%)$ & $39(33.9 \%)$ & 0.197 \\
\hline Rheumatoid Nodules, N (\%) & $153(4.0 \%)$ & $17(14.8 \%)$ & $<.001$ \\
\hline Erosive Joint Disease, N (\%) & $459(11.9 \%)$ & $23(20.0 \%)$ & 0.009 \\
\hline Anti-CCP Antibody Positive, N (\%) & $858(22.3 \%)$ & $45(39.1 \%)$ & $<.001$ \\
\hline Joint Swelling ${ }^{*}, N(\%)$ & $2,861(58.0 \%)$ & $123(68.0 \%)$ & 0.008 \\
\hline Joint Tenderness ${ }^{*}, \mathrm{~N}^{\prime}(\%)$ & $3,728(75.6 \%)$ & $138(76.2 \%)$ & 0.851 \\
\hline $\mathrm{ESR}^{\star \star}$, Mean $\pm \mathrm{SD}, \mathrm{mm} / \mathrm{hr}$ & $22.0 \pm 22.6$ & $30.1 \pm 25.5$ & $<.001$ \\
\hline $\mathrm{CRP}^{\star \star}$, Mean $\pm \mathrm{SD}, \mathrm{mg} / \mathrm{L}$ & $22.5 \pm 13.0$ & $60.6 \pm 25.0$ & 0.086 \\
\hline CDAl, Mean \pm SD & $16.4 \pm 12.3$ & $18.9 \pm 15.7$ & 0.044 \\
\hline DAS28-CRP, Mean \pm SD & $2.6 \pm 1.2$ & $3.1 \pm 1.4$ & $<.001$ \\
\hline DAS28-ESR, Mean \pm SD & $3.3 \pm 1.4$ & $3.9 \pm 1.5$ & $<.001$ \\
\hline SDAI, Mean \pm SD & $20.2 \pm 29.3$ & $28.6 \pm 40.2$ & 0.048 \\
\hline
\end{tabular}

*A total of 4,929 non-ILD and 181 ILD patients had joint swelling and tenderness data.

${ }^{* *}$ Variables were calculated among patients who had available information.

Conclusion: This large real-world RA population provides insight into the burden of ILD in RA pts. Pts with ILD had a higher proportion of comorbidities and RA-related conditions and higher RA activity. Further analysis is warranted to assess the risk factors of ILD and its prognosis.

Disclosure of Interests: Joe Zhuo Shareholder of: Bristol-Myers Squibb, Employee of: Bristol-Myers Squibb, Qisu Zhang Consultant of: I am a paid employee of STATinMED Research which is a paid consultant to Bristol-Myers Squibb Company., Keith Knapp Consultant of: In the last year, I was a paid consultant to Bristol Myers-Squibb Company., 